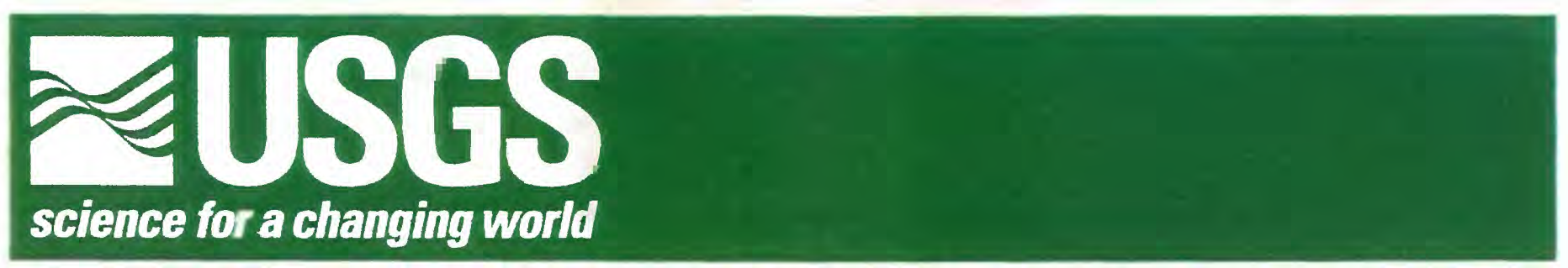

\title{
ASSESSMENT OF STREAMBED SCOUR AT BRIDGES IN INDIANA
}

One of the leading causes of bridge failure is the erosion of streambed sediment from around the supporting abutments and piers. Geomorphic and hydraulic characteristics, streambed material, drift accumulation, as well as bridge characteristics and other streambed-erosion influences were documented during low-flow conditions at more than 5,500 bridge sites in Indiana to assess the processes that affect streambed stability. This documentation was used to assign index values for scour observed at each bridge and a ranking value that indicates the potential for scour at a bridge.

\section{INTRODUCTION}

Bridges represent a considerable investment in materials and labor that make our lives more convenient. When a bridge fails or is not usable, the loss to a community can affect lives and transportation, and public resources must be allocated for bridge repair or replacement. Evaluations of bridge structures and streambeds can identify potential problems and help prevent disruption to community life, transportation, and budgets. To address potential scour-related problems, in 1988, after the 1987 Schoharie Creek Bridge failure in New York, the National Transportation Safety Board recommended that National Bridge Inspection Standards be modified to require an assessment of instability problems caused by geomorphic processes.

A leading cause of bridge failure is the erosion, commonly called scour, of the streambed around bridge abutments and piers. From 1991 to 1995 the U.S. Geological Survey (USGS), in cooperation with the Indiana Department of Transportation (INDOT), collected geomorphic and hydraulic information related to scour at more than 5,500 bridges in Indiana. At each bridge site, streambed and bridge conditions that can contribute to scour were examined and the amount of scour observed, along with the potential for scour, was ranked.

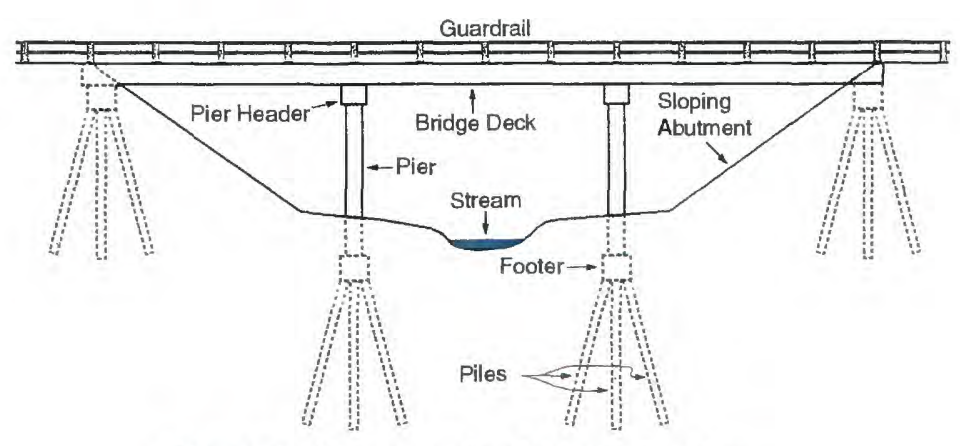

Figure 1. Components of a typical bridge

\section{SCOUR AT BRIDGES}

Bridges are built in many styles and sizes. More than 50 types of bridgesfrom multi-span urban interstates over large rivers to single-lane rural covered bridges over small streams - were examined during the USGS study. Bridges can be constructed with either vertical or sloping abutments (fig. 1), with or without piers, and with or without piles (structural supports driven into the ground). All construction elements have one thing in common: the need for a sound foundation.

All bridges hold the risk for potential failure as a consequence of hydrologic processes. Two principal hydrologic processes or mechanisms that can lead to bridge failure are 1) water or debris impact on the bridge deck with enough force to remove the bridge deck from its supports, and 2) scour of streambed material that can undermine the bridge supports. The USGS bridge evaluation in Indiana focused on scour of streambed material. The three major components of scour at bridges are 1) long-term degradation or aggradation of the stream channel, 2) contraction scour due to constriction of flow or bridge location, and 3) local scour at piers and abutments (Lagasse and others, 1995, p. 40).

\section{FACTORS AFFECTING SCOUR}

Many factors can affect the stability of a stream channel at a bridge site. These include bed and bank material, bridgeopening size, drift accumulation, the angle at which water strikes the bridge supports, and the proximity of a streams's meanders to a bridge.

Bed and bank material--Indiana's surficial geology ranges from sand dunes and glacial sand, gravel, and till in the northern part of the State to bedrock hills in the southern part. Different materials are scoured at different rates. Loosely packed, non-cohesive sediments are more easily eroded than cohesive sediments or solid bedrock. Silt and sand particles are more easily eroded and transported than gravel and cobbles. Although all channels and streambed materials are susceptible to scour, given adequate time and flow conditions, stream channels with stable and well-aligned banks or bedrock streambeds are least likely to have scour-related problems,

Bridge-opening size - If the flow area (width $\mathrm{x}$ depth) at a bridge is less than the flow area upstream from the bridge, flow can be constricted when it passes through the bridge opening. When flow is constricted, velocity, turbulence, and consequently, erosion potential increase and in turn can cause increased scour within the bridge opening or downstream from the bridge.

If the water surface rises above the elevation of the bridge deck's lower sections, flow can be constricted vertically. A vertical constriction can increase the likelihood for streambed scour. Sections of the road approaching many bridges are lower than the lowest part of the bridge 
deck (fig. 2). This "dip" in the road provides flow relief, thereby reducing flow velocities and horizontal pressure on the bridge deck. Each bridge in this study was examined for features providing flow relief.

Drift (floating debris) accumulation-Drift lodged against a bridge pier can contribute to scour. Bridge piers are stationary objects in a stream's flow path, making it easy for floating trees and other debris to become lodged on the upstream side of the bridge support. As drift accumulates and the drift pile enlarges, the size of the bridge opening decreases and flow is constricted (fig. 3). This constricted flow can increase the potential for scour. If water cascades over the top of the drift pile, the cascading effect can cause scour on the downstream side of the pile. If a large drift pile floats during periods of high flow, flow can be directed downward, which will increase the potential for scour beneath the drift pile

Attack angle-When water strikes a pier, water is deflected downward and scour can occur around the pier. Scour results mainly from vortices that develop in front of and along the sides of the pier (fig. 4). If the pier is aligned so the side of the pier obstructs flow (effectively making the pier wider), scour potential can be magnified by the constriction of flow and the increased intensities of the vortices created as water strikes the pier.

Proximity of stream meanders to a bridge - Bridges generally are designed to be aligned perpendicular to the approaching flow, but changes in a stream's course because of channel meandering

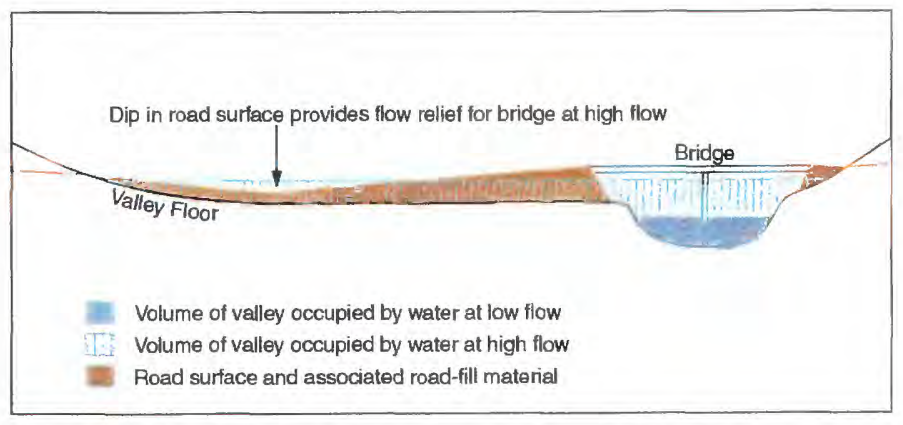

Figure 2. Cross-section view showing lowered road section that provides flow relief for a bridge during a flood.

may change the angle at which flow approaches the bridge. If a meander develops close to a bridge, the angle at which water impacts piers and abutments can increase, causing scour problems associated with high attack angles to intensify (fig. 5). In extreme cases, meandering can change the course of the stream so significantly that sections of the road leading to the bridge are in danger of being eroded.

\section{OBSERVED AND POTENTIAL SCOUR INDICES}

Observed-scour index-The information collected at each bridge site was analyzed, and an index was developed by the USGS and INDOT to rank the existing scour conditions at bridge sites (Robinson and Thompson, 1995). The ordering of the observed-streambed-scour categories in this index was based on the relative severity of each category. The index (table 1) ranges from 10 to 0 , with 10 representing bridges with the least severe scour conditions and 0 representing bridges with the most severe observed-scour conditions.

Table 1. Observed-scour index used to rank bridges in Indiana

\begin{tabular}{l}
$\begin{array}{l}\text { Observed-scour } \\
\text { categories }\end{array}$ \\
\hline
\end{tabular}

No observed streambed scour

Scour hole(s) only

Local scour at abutment(s) only

Local scour at pier(s) only

Local scour at pier(s) and scour hole(s)

Blowhole

Vertical abutment(s) with footing(s) exposed

Sloping abutment(s) with pile(s) exposed

Vertical abutment(s) with pile(s) exposed

Pier(s) with footing(s) exposed

Pier(s) with pile(s) exposed

The observed-scour-index value for each bridge is not cumulative; it is dependent only on the most severe scour condition observed. Figure 6 shows the percentage of bridges in each county that have an observed-scour-index value less than 5 (index values less than 5 represent significant scour conditions). Bridges built on bedrock commonly are constructed with footings exposed and therefore were excluded from the data set used to generate figure 6.

An index of this type has limitations. All observed-scour observations were made at low-water stages. High water prevented bridge-site examinations, and some scour related to high water may have been obscured by deposition of sediment since the scour event. Another limitation is the inherent assumption that equivalent effects of scour on an abutment are less threatening to a bridge than are the same effects on a pier. This assumption may not

Figure 3. View of flow paths around piers and a drift pile at bridge opening. 


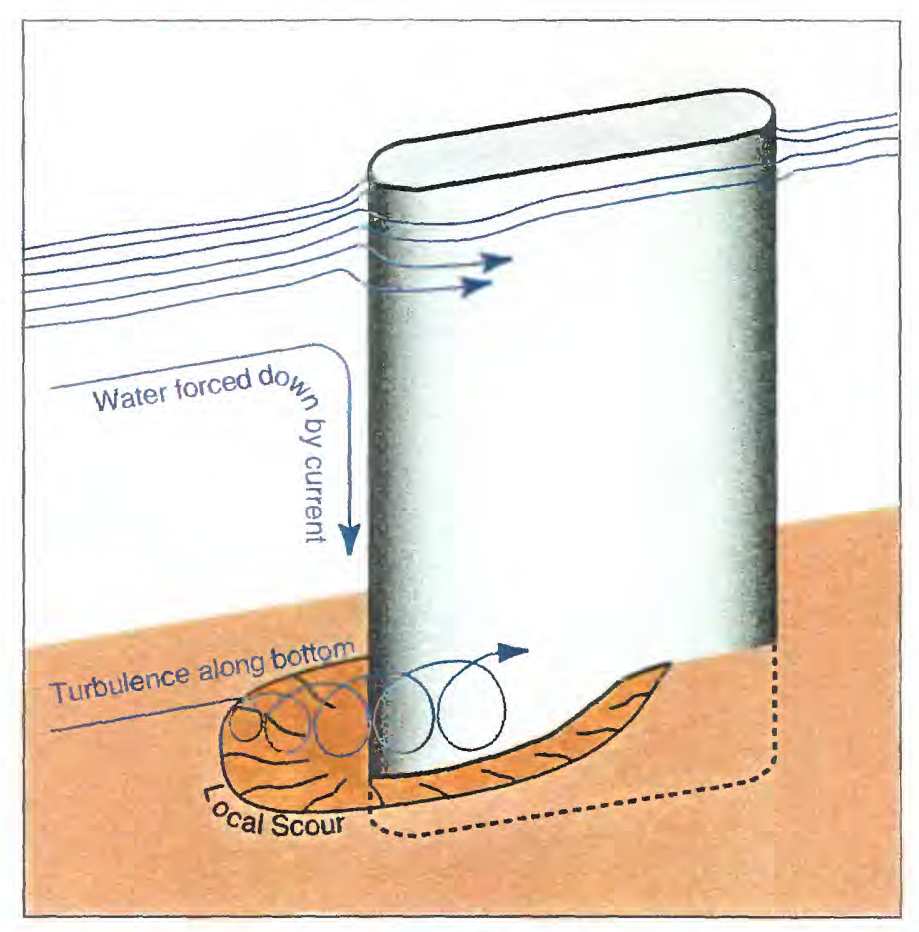

Figure 4. View of flow paths around a pier and associated local scour mechanisms.

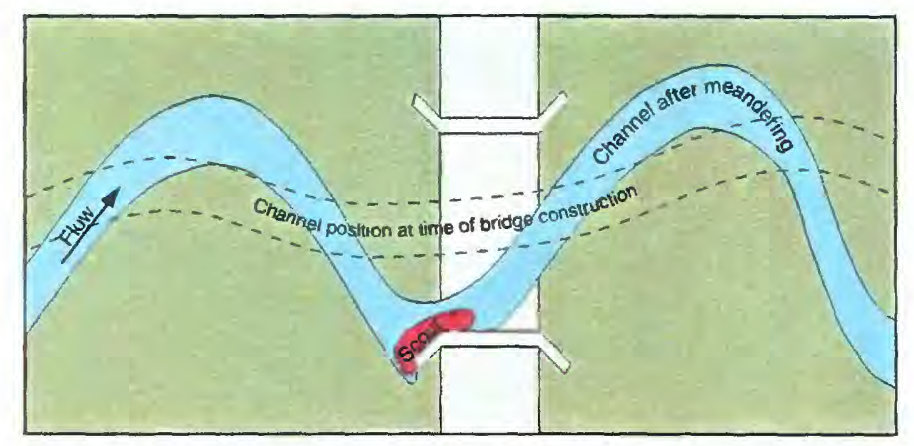

Figure 5. Plan view of meandering river near bridge showing channel migration and resulting scour.

be valid but is based on the concept that the embankments offer some degree of protection and stability to the abutments, whereas embankments do not offer this same stability to the piers (Robinson and Thompson, 1995).

Potential-scour index - The USGS and INDOT developed a method to rank the potential for scour at a bridge site. This ranking system is based on consideration of four factors that influence the potential for scour: bed material, attack angle, drift (debris) blockage, and contraction ratio (table 2). The potential-scour-index value for a given site is the summation of "weighting points" assigned to the potential for scour posed by each factor. The only exceptions are for sites where a bridge has been built on bedrock or is well protected by riprap; for these sites, the potential-scour-index value is set to 0 . If the summation of points is negative, the potential-scour-index value is raised to 0 . Potential-scour-index values can range from 0 (least potential for scour to occur) to 100 (most potential for scour to occur) (Hopkins and Robinson, 1997). Figure 7 shows the percentage of bridges in each county with a potentialscour-index value greater than 30 . Any bridge site with a potential-scour-index value greater than 30 probably has at least one significant contributing factor that is assigned a high weighting value or has several contributing factors that are assigned moderate to low weighting values that make the potential for scour significant at that site.
This potential-scour index has limitations. Many factors that can affect channel instability (channel gradient, streamflow velocity, flood channel width, the potential for lateral erosion or for the bridge to trap debris) were not included in the datacollection process or the index. Velocity and depth, for example, change with changes in flow. Other factors (bank material and meander location) have been left out because similar characteristics (bed material and attack angle) are included.

\section{FUTURE STUDY NEEDS}

The streambed-scour documentation described in this report is a step towards understanding streambed scour at bridges and the processes that affect scour.

Table 2. Potential-scour index used to rank bridges in Indiana

\begin{tabular}{cc}
\hline $\begin{array}{c}\text { Potential-scour } \\
\text { factors }\end{array}$ & $\begin{array}{c}\text { Weighting } \\
\text { points }\end{array}$ \\
\hline Bed material & \\
Sand & 30 \\
Silt/Clay & 18 \\
Gravel & 0 \\
Cobble/Boulder & -12 \\
Attack angle & \\
$>45^{\circ}$ & 30 \\
$26^{\circ}-45^{\circ}$ & 24 \\
$10^{\circ}-25^{\circ}$ & 18 \\
$<10^{\circ}$ & 0 \\
Sites with high debris & \\
blockage & \\
(percent of opening & \\
blocked by debris) & \\
$>20 \%$ & \\
$16-20 \%$ & 20 \\
$11-15 \%$ & 16 \\
$6-10 \%$ & \\
$0-5 \%$ & \\
All other sites & \\
[(approach width / & \\
channel width at & \\
bridge) - 1] x 100 & \\
Contraction ratio & \\
$26-0 \%$ & \\
\hline
\end{tabular}




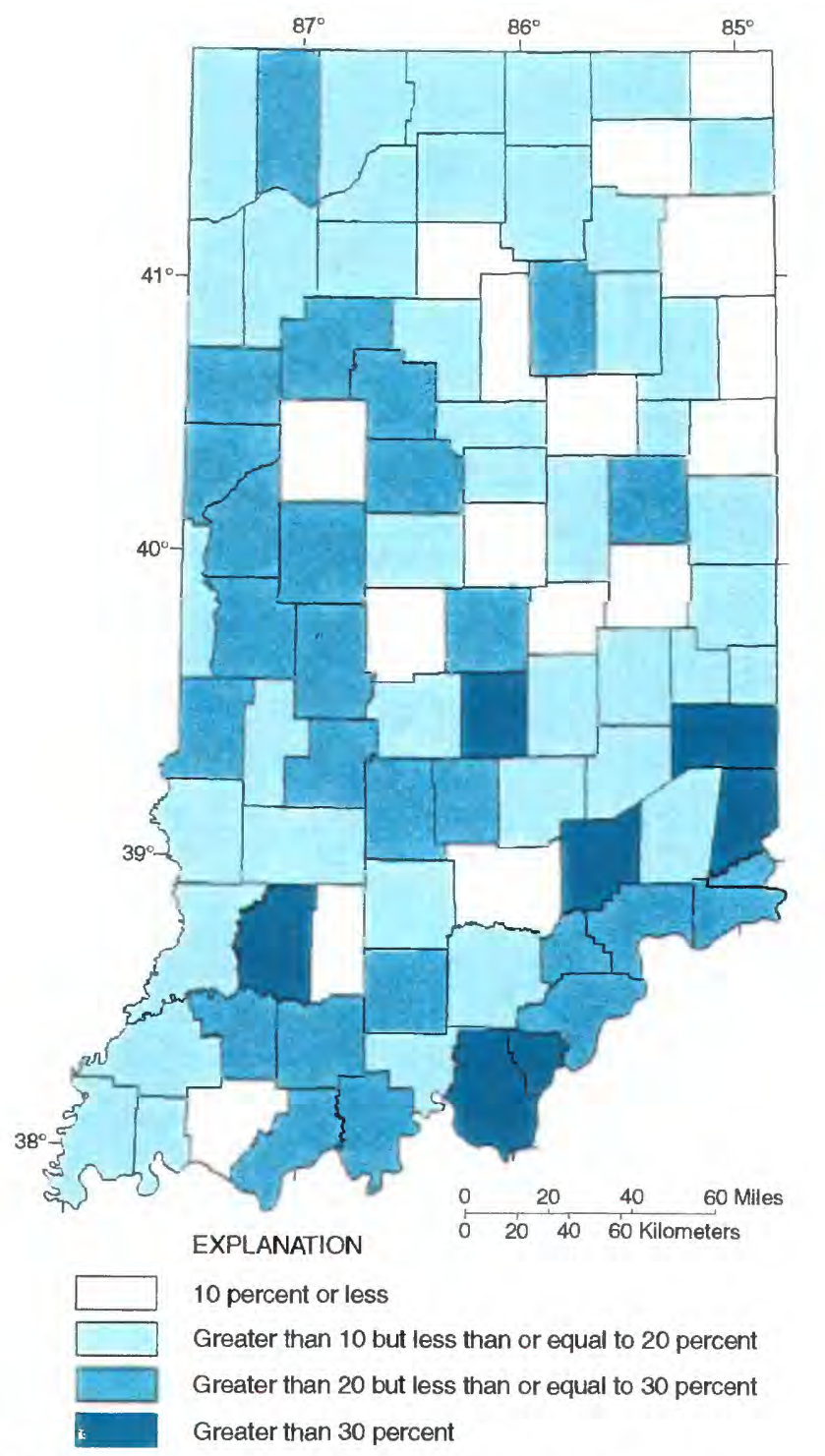

Figure 6. Percent of bridges in each Indiana county with an observed-scour-index value less than 5 (Index values less than 5 represent significant scour conditions).

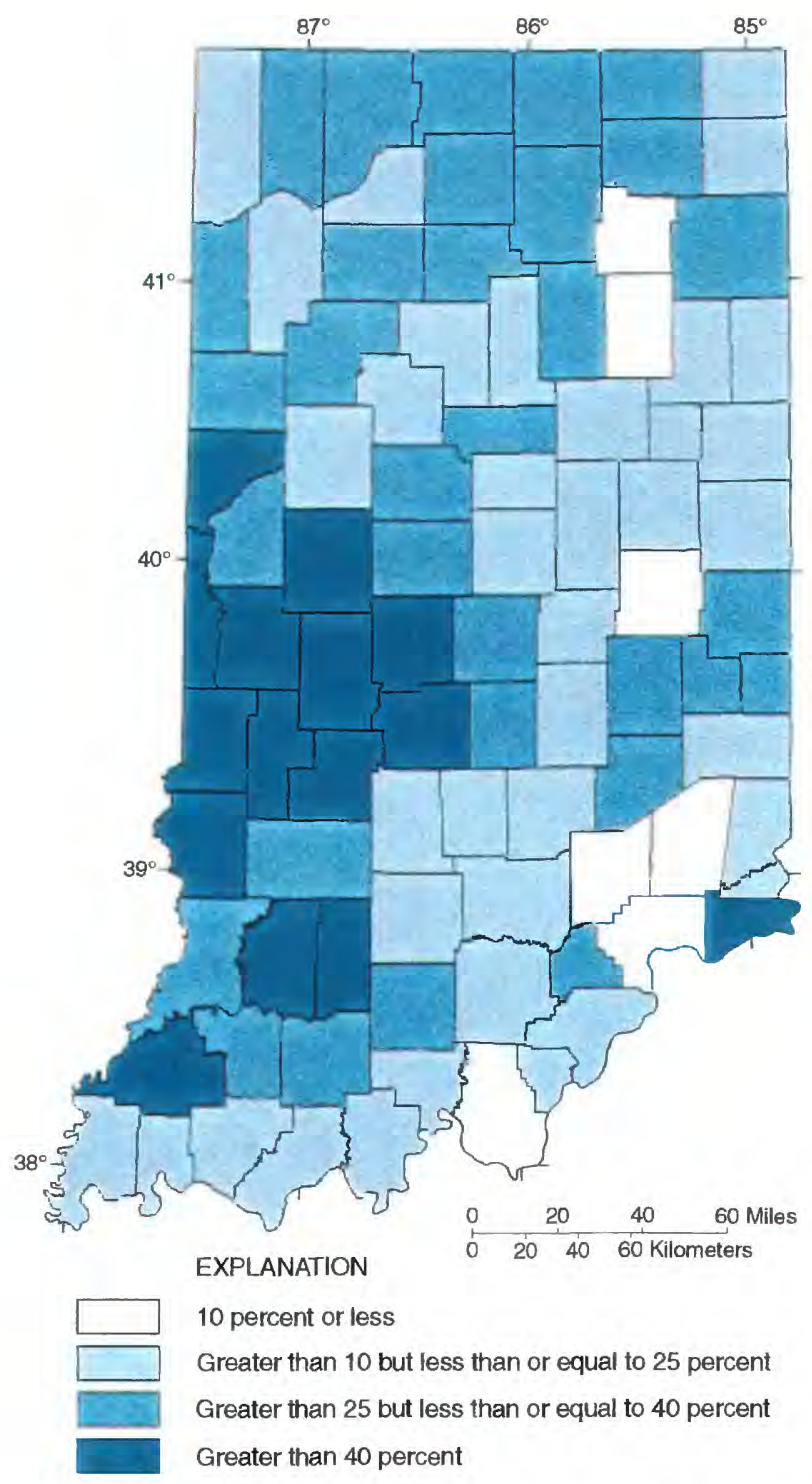

Figure 7. Percentage of bridges in each Indiana county with a potential-scour-index value more than 30 (Index values greater than 30 indicate significant potential for scour).
Detailed, expanded site-specific bridge evaluations are needed to gain additional knowledge about predicting streambed scour and the various processes that affect scour around bridge piers and abutments. This knowledge then can be applied to the design of bridges to make them less susceptible to scour.

\section{-Gary Bennett}

http://www-dinind.er.usgs.gov

\section{SELECTED REFERENCES}

Federal Highway Administration, 1988 Scour at bridges: Federal Highway Administration Technical Advisory $5140.20,132 \mathrm{p}$

Hopkins, M.S., and Robinson, B.A., 1997, Data base for assessments of streambed scour and channel-instability at selected bridges in Indiana, 1991-1995: U.S. Geological Survey Open-File Report 97-419, $17 \mathrm{p}$.

Lagasse, P.F., Schall, J.D., Johnson, F., Richardson, E.V., and Chang, F., 1995 , Stream stability at highway structures: Federal Highway Administration Hydraulic Engineering Circular 20, Publication FHWA-IP-90-014, 144 p.

Miller, R.L., and Wilson, J.T., 1996, Evaluation of scour at selected bridge sites in Indiana: U.S. Geological Survey WaterResources Investigations Report 95-4259, $225 \mathrm{p}$.

Mueller, D.S., Miller, R.L., and Wilson, J.T., 1994, Historical and potential scour around bridge piers and abutments of selected stream crossings in Indiana: U.S. Geological Survey Water-Resources Investigations Report 93-4066, 109 p.
National Transportation Safety Board, 1988 , Highway accident report - Collapse of New York Thruway (I-90) bridge over Schoharie Creek, near New Amsterdam, New York, April 5, 1987: National Transportation Safety Board Report NTSB/ HAR-88/02, $168 \mathrm{p}$.

Robinson, B.A., and Thompson, R.E. Jr., 1993, An efficient method for assessing channel instability and scour near bridges in Proceedings, 1993 National Conference on Hydraulic Engineering. San Francisco, California, July 25-30: American Society of Civil Engineers, Hydraulics Division, vol. 1, p. 513-518.

Robinson, B.A., and Thompson, R.E., Jr., 1995, An observed-streambed-scour index for selected bridges in Southwestern Indiana, 1991: U.S. Geological Survey Water-Resources Investigations Report 95-4264, 6 p. 